\title{
The Crisis of Religious Identity and Religious Landscape in Contemporary Brazil
}

\author{
Alberto da Silva Moreira \\ Pontifical Catholic University of Goiás, Goiânia, Brazil \\ Email: alberto-moreira@uol.com.br
}

Received 10 August 2014; revised 27 September 2014; accepted 12 October 2014

Copyright (C) 2014 by author and Scientific Research Publishing Inc.

This work is licensed under the Creative Commons Attribution International License (CC BY). http://creativecommons.org/licenses/by/4.0/

c) (i) Open Access

\begin{abstract}
In the processes of economic, political and cultural globalization, there is a crisis within traditional meaning-producing and identity-creating institutions, such as the state, family, school and traditional religions, going on in Brazil and in other Latin American countries. If in the 1930s Brazilian and Catholic were considered as two sides of the same national religious identity coin, today Brazil is rapidly becoming a multi-cultural and multi-religious country. It remains the largest Catholic country, and has also already been the largest Pentecostal and the largest Spiritualist country in the world. In addition, other religious minorities, such as African-Brazilian religions, Buddhists, Muslims and Jews increasingly occupy the public sphere. Parallel to this shift, there is a significant effort being put forth by many Brazilian and South American religious communities to expand on a global level, such as the Pentecostals, charismatic Catholics, Spiritualists and AfroBrazilian communities. This presentation analyzes the causes and the data related to this religious and identity change and highlights some trends for the future.
\end{abstract}

\section{Keywords}

Religion, Brazil, Religious Identity, Religious Diversity, Catholic Church

\section{Introduction}

In the 1930's Cardinal Sebastião Leme, Archbishop of Rio de Janeiro, coined an expression that had made history ever since: to be Brazilian means to be Catholic; catholicity constitutes the historical identity of Brazilians. At that time, the Republican State had already been officially separated from the Catholic Church for forty years, but under the leadership of Cardinal Leme and President Getúlio Vargas, a strong movement began to reunite the Church and State. Vargas needed support and legitimacy for his government, which had been established by a coup d'État; the Catholic Church sought to reapproximate itself with the government in order to reinforce its 
presence and influence in the public sphere. Such an alliance between the highest Church and political officials was celebrated in 1931, with the inauguration of the Christ, the Redeemer statue, on Corcovado Mountain in Rio de Janeiro. In his speech, Cardinal Leme stressed that "either the State recognizes the God of the people, or the people will not recognize the State" [1]. In an apparent confirmation of Cardinal's Leme verdict, the statue of Christ, the Redeemer soon went from a religious catholic image to a cultural icon, and indeed to veritable symbol of Brazilian national identity [2].

Nevertheless, when we apply the religious identity concept to the Brazilian religious field, we cannot suppose that such fixed and unchangeable cultural or religious identities exist. The historical formation process of religions in Brazil is quite long and complex, and is characterized as much by forced and conflictive approximation as by the negotiated, pacific and interactive living together with very diverse religious traditions. This process, sometimes called syncretism, hybridism, mestizaje, continues in full swing. It is comprised of, in Braudel's words, both long-term continuities (longue durée), and short-term processes (brève durée), but above all of the dynamics of continuity within the ruptures [3]. Many times the previous religious reference receives contributions, incorporates elements from new references, but essentially retains its internal structure. Other times, the previous symbolic system appears to be replaced by other symbolic systems, "possibly retaining elements from the first symbolical system inserted in the new significant order" [4].

This transformation process of beliefs became more intensive in the recent cultural globalization, often producing combinations, juxtapositions, contradictions, overlapping, refusal and parallelism of religious elements. There is no linear and foreseeable development in this realm, and often there is a clashing of pre-modern, modern and hyper-modern elements in the same context, at the same time. Permeability, transit and porosity seem to mark this process. The identity crisis thus becomes more or less dramatic, with a greater or lesser degree of awareness of what one loses and what one gains, in the end process of arrangement and re-composition of symbolic borders among the different religious identities.

In the following, the author first offers a quick incursion through the pre-history of the recent religious diversity in Brazil; secondly, he comments upon the religious landscape as outlined by the most recent demographic Census of 2010, and, lastly, tries to outline some trends and perspectives for the future in the religious and cultural field.

\section{The Historical Formation of Brazil's Religious Diversity}

Cardinal Sebastião Leme's approach to the Catholic identity of Brazilians expressed, of course, a desire and a political-religious project of those sectors within the Church represented by his religious figure. However, his assertion also reproduced an image that ultimately remained in the social imaginary: that Brazil is a Catholic country, in fact the greatest Catholic country in the world. Mutatis mutandis, and keeping the just proportions, a similar image was built around all Latin-American countries: that a common colonial past, that shared or similar religious, cultural, political, and economic heritage had transformed Latin America in a essentially Catholic continent. In the common sense, Latin America, and in particular Brazil, appear as a continent and as a country built around Catholic devotions, religiosity and Catholic popular culture. As is well known, in the past this cultural heritage has been used in a simplistic manner to even explain the relative economic underdevelopment of the region.

Nevertheless, the notion of a religious and cultural identity has its grounds. After all, the strong Catholic presence in Latin America was not bound only to devotions, the calendar, and the cult of the saints, topography names, and dozens of sanctuaries, pilgrimages, popular festivals and Catholic traditions. It was also based on the long-lasting influence of countless Catholic institutions, such as brotherhoods, lay associations, dioceses, parishes, schools, universities, hospitals, homes for retired people and orphans, radios, televisions, journals, magazines, clubs, printing houses, NGOs and other pastoral initiatives or political institutions inspired by or linked to the Catholic Church. Cardinal Leme himself, wisely so, did not want to found a Catholic political party, as he feared a Catholic party would just divide what he considered to form a religious, political and cultural unity: Brazilian Catholicity. He satisfied himself with the founding of a Catholic electoral league to influence the elections.

As we know, this religious unity was backed by nearly 400 years of the Royal Patronage regime, which made Catholicism the official religion of the Portuguese empire and prohibited all other religions and creeds in the colonies. This exclusivity of Catholicism continued after Brazil's independence (1822), during the Brazilian 
empire, until the arrival of the Republic in 1899. The Patronage regime reduced to a minimum the Pope's and the Vatican's influence over the Catholic Church in Brazil, whereby improving to a maximum the authority of Portuguese kings, and later on of Brazilian emperors, to manage and control the Church. Due to many reasons, including the lack of priests, this situation brought about a popular Catholicism, based on lay and family-lead initiatives, markedly devotional, with much prayer and less theology, coupled with the cult of saints and magical elements, which are typical of an agrarian society that is isolated, dispersed over a huge territory, and organized under authoritarian patterns. Therefore, Brazilian Catholicism, so highly praised by Cardinal Leme, has never been uniform: in its long historical formation, whose medieval Iberian roots are visible still today, it not only assimilated and incorporated religious elements from the native populations, the African slaves and later from Spiritualism; it re-interpreted official Catholicism according to its own symbolical codes.

Undoubtedly this process was marked by conflicts, tensions, resistance, negotiations and, not rarely, violence. Symbolic and military violence, such as, for example, the expulsion of French Calvinists from Rio de Janeiro (1560) and Maranhão (1615), and Dutch reformists from the Northeast of Brazil (1654). Despite all of this, at least since 1808, when the Anglicans came to Rio, or 1834, when the German Lutherans arrived in the mountains of Petrópolis and shortly thereafter in the South, there were other religious identities existing explicitly and autonomously. Throughout the 19th century, the great majority of classic Protestant churches arrived in Brazil; and after 1910, in succeeding waves coming from the United States, the Pentecostals. Spiritualism arrives in 1865 in Brazil, just a few years after its foundation by Alan Kardec in France. Among the Afro-Brazilian religions, Candomblé grew after the Abolition of Slavery in 1888; Umbanda, which aggregates elements from Catholicism, Spiritualism, and Candomblé, begins to organize itself around 1900. Other Afro-Brazilian religiosities assumed within the context of a secular state, which provided equality of rights and religious tolerance, a more conscious and self-confident presence in the Brazilian society.

A few words about the Jews and Moslems in Brazil; The Jews, during the colonial era, were often persecuted and forced to convert to Catholicism (cristãosnovos). They experienced a relative period of calm during the Dutch invasion of the Northeast of Brazil, where they built the first synagogue of the Americas. However, when the Dutch were defeated in 1654, the majority of the Jews went back to the Netherlands, some made roots in the wilderness of Northeast and still others settled in the Antilles and Manhattan Island, where they founded the first synagogue of the US. After that, the Jews only came onto scene again at the end of 19th century; there was an immigration from Morocco to the Amazon region during the rubber boom. Since this time several groups of Jewish immigrants have come to Southeastern Brazil, primarily from Eastern Europe, especially because of the Nazi persecution.

Islam arrived in Brazil along with the African slaves, especially those who came from Sudan. During the entire colonial period, Africans could not openly practice their religions. As such, only few traces of Islamic faith have survived until the current day. A new phase of Islamic presence began with the immigration of Syrians, Palestinians, Lebanese, and Egyptians after the Second War. More recently, after 1970, many Lebanese and Palestinian Muslims came to Brazil because of the civil war in Lebanon [5]. The Arabian Muslims are concentrated in the city of São Paulo and in the state of Paraná, in the frontier region between Argentina and Paraguay. Without a doubt, this immigration flow of Lebanese and Syrians is much less intense than the first one of Christians. The first Lebanese and Syrian immigrants went to Brazil between 1860 and 1890; as Christians, they suffered persecution by the Ottoman Empire in Lebanon. Economic, political, cultural, and religious factors caused the migration flow, especially after 1909, when the Turks imposed military service on the Christians. The Brazilian Emperor, Peter II, visited Lebanon and the Middle East in 1876, inviting the people to emigrate to Brazil ${ }^{1}$. Today Brazil is thought to have the largest Lebanese population in the world, with approximately 6 million Lebanese descendants, half of them living in the state of São Paulo. Religiously speaking, a portion of them is represented in the statistics shown in following under "Igreja Ortodoxa" (Orthodox Church).

Other immigrants from Asia carried their religion with them when they arrived in Brazil. The Japanese brought, since 1908 and in succeeding waves, Buddhism and Shintoism. After the Second World War new Japanese religions such as Perfect Liberty and Seicho-no-Iê arrived in Brazil [6]. Besides the big "immigration religions” there are many other groups, like Korean Protestants, American Baptists, Hinduists and Baha'I. Other religious groups could be described as “missionary religions”, such as the Pentecostals, the Jehovah’s Witnesses,

${ }^{1}$ Dom Pedro II himself was born in the palace of Quinta da Boa Vista, which was previously the house of the Lebanese merchant Antun Elias Lubbos. Lubbos gave it up to the Portuguese king D. João VI in 1808, when the king and the Portuguese court transferred to Rio de Janeiro. 
Mormons, some esoteric traditions, Tibetan Buddhism and many other groups. There is no lack of a national Brazilian Catholic Church, which was created after 1945, and remnants of indigenous religions. Although minorities, all these religious communities construct a pluralistic religious landscape in contemporary Brazil.

In fact, in the 1930's, at the same time as when Cardinal Leme stressed the Catholic identity of Brazilians, there was already a great diversity of religious creeds and beliefs in full development in Brazil. Many others autonomous groups came afterwards. Nevertheless, the demographic weight and the cultural influence of Catholicism gave a pillar of historical reality to the Cardinal's words. Today this reality has taken on a very different appearance. Catholicism continues to be the religion of most Brazilians, but over the last thirty years a new religious and cultural landscape has begun to arise; one that is very different from the scenario Dom Leme witnessed at the start of the twentieth century. Brazil is becoming a multi-religious country, or at least, a multiChristian country. In following, we observe the long-range chart (Figure 1) in terms of religious belonging in Brazil.

The data presented in the 2010 Census [7] depicts the relative increase in religious pluralism and religious indifference, but above all the growth of Pentecostalism and the diminishing of Catholics within the Brazilian religious landscape. The next chart (Figure 2) is a better indication of proportion among the various religious confessions.

\section{Interpreting the Religious Landscape in Contemporary Brazil}

Some conclusions can be made based on this Census data, published only in 2012, and the most important are the following:

1) The Catholic Church continues loosing members throughout the 20th century, and this trend has accelerated over the past 20 years;

2) Protestant Churches experienced rapid growth, mainly the Pentecostal sector;

3) The number of people without a religious belonging increased;

4) The Afro-Brazilian religions diminished;

5) Brazil is becoming a multi-religious country or at least a country with a plurality of Christian confessions.

a) Number of Catholics on the Decline

As noted in the chart, Catholicism is still the religion of the majority, but its historically declining curve sets forth: in 2010, 64.6\% of the population declared itself Catholic; in 2000 that percentage was 73.7\%. In 2010, for the first time in history, there was a loss in absolute numbers: levels of Catholics declined from 125 million in 2000 to 123 million in 2010. Until then, the declining percentage had been compensated by the population growth. In some regions, like the States of Rio de Janeiro, Rondonia, some big cities and zones of recent immigration, like the Amazon, Catholicism reaches only around 50\% of the population.

b) Pentecostals on the March

There was a great increase in Protestants, above all in Pentecostal and Neo-Pentecostal Churches. Combined, the number of Pentecostals and (classical) Protestants reached 42.3 million people in 2010, compared with 26 million in 2000. The Pentecostal growth was very slow in the beginning; it took 80 years to appear statistically: In 1991, they were only 5.6\%. But after the 1970's their increase rate accelerated very quickly: in 2010 they were already at $13.3 \%$, embracing around 26 million people, or $60 \%$ of all Protestants. Some experts estimate that these numbers should reach 35 - 30 million members. What are the causes for this shift? In the last eighty years, Pentecostalism managed to culturally engrain itself in the Brazilian society, much more than classical Protestant churches managed to do in the past. Pentecostals assumed the syncretistic religious pattern, invested in healing, exorcism, miracle, empowerment of the individual in a society lacking basic resources of income, health, education; a society that went through an accelerated urbanization and industrializing process, deep economic and cultural changes, that still lives in insecurity, high competition and increasing individualism. The reasons for the numerical growth are therefore both a favorable external environment, as well as the internal capacity of Pentecostalism to adapt charisma to the daily life of urban masses. Compared to traditional churches and religions, Pentecostals have included both an aggressive proselytizing activity and a highly positive stance in relation to wealth and prosperity in their ethos.

A new popular Pentecostalism is on the way, with its own culture, symbols and icons; Pentecostal churches want to show a strong presence in the public sphere, in the political arena, in the media and in the economy. As shown in Table 1, the biggest churches are the Assembly of God (12.3 million), the Christian Congregation in 


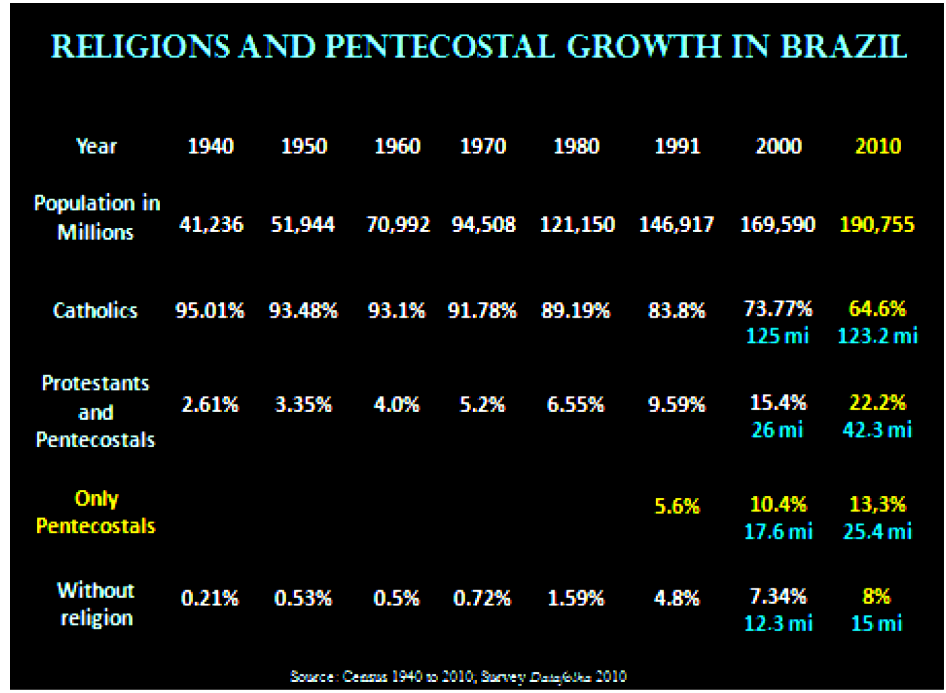

Figure 1. Population and religions growth from 1940 to 2010.

Religião
Católica Apostólica Romana
Evangélicas
Sem religião
Espirita
Outras religiosidades cristãs
Testemunhas de Jeová
Não determinada e multiplo pertencimento
Umbanda e Candomblé
Católica Apostólica Brasileira
Budismo
Igreja de Jesus Cristo dos Santos dos Últimos Dias
Não sabe
Novas religiões orientais
Católica Ortodoxa
Judaísmo
Tradições esotéricas
Tradições indigenas
Espiritualista
Sem declaração
Islamismo
Outras religiosidades
Hinduismo

$\begin{array}{rr}\text { Pessoas } & \text { \% } \\ 123.280 .172 & 64.63 \\ 42.275 .440 & 22.16 \\ 15.335 .510 & 8.04 \\ 3.848 .876 & 2.02 \\ 1.461 .495 & 0.77 \\ 1.393 .208 & 0.73 \\ 643.598 & 0.34 \\ 588.797 & 0.31 \\ 560.781 & 0.29 \\ 243.966 & 0.13 \\ 226.509 & 0.12 \\ 196.099 & 0.10 \\ 155.951 & 0.08 \\ 131.571 & 0.07 \\ 107.329 & 0.06 \\ 74.013 & 0.04 \\ 63.082 & 0.03 \\ 61.739 & 0.03 \\ 45.839 & 0.02 \\ 35.167 & 0.02 \\ 11.306 & 0.01 \\ 5.675 & 0.00\end{array}$

Figure 2. Religions in Brazil according to the 2010 census.

Table 1. The largest Protestant and Pentecostal Churches in Brazil-2010 Census.

\begin{tabular}{|c|c|c|}
\hline THE PROTESTANT AND PENTECOSTAL FIELD & 2000 & 2010 \\
\hline Traditional-Classical Protestant Churches & 6,939,765 & $7,686,827$ \\
\hline Baptists & $3,162,691$ & $3,723,853$ \\
\hline Adventists & $1,209,842$ & $1,561,071$ \\
\hline Lutherans & $1,062,145$ & 999,498 \\
\hline Presbyterians & 981,064 & 921,209 \\
\hline Methodists & 340,963 & 340,938 \\
\hline Pentecostal Churches & 17,617,307 & $25,370,484$ \\
\hline Assembly of God & $8,418,140$ & $12,314,210$ \\
\hline The Christian Congregation in Brazil & $2,489,113$ & $2,289,634$ \\
\hline The Universal Church of the Kingdom of God & $2,101,887$ & $1,873,243$ \\
\hline Church of the Foursquare Gospel & $1,318,805$ & $1,808,389$ \\
\hline God is Love Church & 774,830 & 845,383 \\
\hline Pentecostals undetermined or without formal belonging & & $9,218,129$ \\
\hline
\end{tabular}


Brazil (2.3 million), the Universal Church of the Kingdom of God (1.8 million), and the Baptists (3.7 million). Classic Protestants, like Lutherans and Presbyterians remain stagnant, but the Neo-Pentecostal churches prosper; they constitute what we call Neo-Pentecostalism, a variation of classical Pentecostalism which puts strong emphasis, beyond healing, glossolalia and gifts of the spirit, on wealth gospel, exorcism, war theology against the devil and a very active stance vis-à-vis life and business. Neo-Pentecostalism has abandoned the old Pentecostal ascetic ethos, and proposes happiness here and now through a prosperous life based on consumption [8].

c) Increase in People without Religious Belonging

Other recent developments that have caught the attention of the religious field in Brazil is the increase of those people who declare no religious belonging or no religious faith. It doesn't necessarily mean that they are atheists; research shows the contrary, with most of them still believing in God or in a superior entity. In 2000, this group represented $7.3 \%$ of the population; in 2010, they reached $8 \%$, which means more than 15 million people. This datum seems to show that the privatization process of faith or the weakening of religious institutional mediation continues to grow.

d) A Fall Back among Afro-Brazilian Religions

Among the minority religious groups that remained stable or decreased are the Afro-Brazilian credos, especially Umbanda and Candomblé-practiced only by $0.3 \%$ of the Brazilian population. One reason for the loss of members by the Afro-Brazilian cults during recent years could be the fact that they suffered heavily from symbolical attack by the Neo-Pentecostals. Firstly, Neo-Pentecostals demonize the cultic practices of Umbanda and Candomblé; on the other hand, they appropriate their cults and deities in order to demonstrate power and control over them.

e) Brazil is becoming a Plural Religious Country

The new religious pluralism must be seen as a social phenomenon, despite the fact that almost $85 \%$ of the population declare themselves to be Christians. That is to say, the pluralism remains within the symbolical boundaries of Christianity. But new kinds of interaction between the religious institutions and religious groups have emerged, creating new conflicts, alliances, defining realms, forging a popular Pentecostal culture, changing the political balance, fostering new missionary fronts, both inside and outside the country. Big changes happened in ever-shorter periods: new churches come and go and the religious mobility sped up cultural transformations.

\section{Lasting Trends and Provisional Findings about the Religious Landscape in Brazil}

The major change linked with the growth of Pentecostals was their strong presence in the public sphere-they became a powerful religious minority, conquered a new consciousness and a confident self-image. Mega churches and temples are under construction in major Brazilian cities-marking the urban landscape with a new aesthetics of pride and victory. Backing this change stood the heavy investments made by Pentecostal and Neo-Pentecostal churches in media and politics since the mid-eighties: they bought their own radio and TV networks and paid for broadcasting time on other networks; they also developed a strategy to take an active role in the political scene in Brazil. To ensure their political interests, Pentecostal churches began to plan and to finance the election of their own representatives in the Parliaments, within the local, regional and national political sphere. In the beginning, they stood closer to the right, but later moved pragmatically to the center. Many of them want a Pentecostal president in Brasilia. On the other hand, politicians of all parties try today to conquer the Pentecostal vote, making them a highly disputed electoral sector. After some years of mutual mistrust, Pentecostal and Catholic politicians occasionally build an ideological front in the Congress, especially when family-related, moral and sexual issues are under discussion.

Inside the Pentecostal subfield, a Neo-Pentecostalization process is passing through the old Pentecostal churches, creating "clone churches" of the most successful Neo-Pentecostal ones, such as the Universal Church of the Kingdom of God. However, there were also heavy losses in the public image-Pentecostal pastors have frequently been linked to money scandals and manipulation of the poor. Alongside a differentiation and specialization process, there has been an increase of crude, aggressive competition within the religious field, especially within the Pentecostal subfield. Maybe reflecting a more critical position, a new category of believers emerged out of the Census data: the Pentecostals without formal belonging to any specific Pentecostal church.

With all its ups and downs, Catholicism greatly influenced the Brazilian culture and society. It is not clear which changes or cultural contribution the new popular Pentecostalism will bring. This issue is at the center of 
heated discussions on the topic at this moment; some people, like David Martin, think that Pentecostalism will bring a new productive and Protestant ethos, which will help to establish a real capitalist economy in Brazil. Others think that the old syncretistic religious matrix in Brazil will digest Pentecostalism and accommodate it to its own popular patterns. It is true that Pentecostalism has already pushed for strong detraditionalization and individualization processes.

The Catholic Church reacted by closing itself off, also making investments in media and assuming many forms of Pentecostal spirituality and aesthetics into its own practices and liturgy. The Pentecostal influence in the Catholic Church creates what is called the Charismatic Renewal Movement [9]. These charismatic oriented groups grew steadily and developed many different communities, such as the New Communities of Life (Canção Nova and Shalom). Some of them were with a stark engagement in missionary activities abroad and over the Internet. The politically engaged and socially critical movement of Liberation Theology, which has marked the religious and political scene in Brazil since the seventies and for almost thirty years, lost its influence. Nevertheless, it helped to transform the country's political culture, to reestablish democracy and to bring about a profound change in the pastoral consciousness of Catholic Church in Brazil, foremost to the Catholic understanding of the political role of the Church in society. The movement has experienced a warm international reception since its beginnings in many contexts outside Latin America, such as in South Africa, India, Sri Lanka, Philippines and in Palestine.

The Brazilian society and culture have become more porous and adaptable to the macro transformations imposed by the international expansion of market economy. The importation of a greater plurality of typically globalized religious movements, such as the New Age tradition, the soft varieties of Buddhism, Esoteric and nonconventional religiosities insert the country into or reinforce its place within the global circulation of symbolical goods, ideas and imaginaries.

\section{Funding}

Published under the auspices of CNPQ-FAPEG-PRONEX.

\section{References}

[1] Azzi, R. (1994) A Neocristandade: Um projetorestaurador. Vol. V, Paulus, São Paulo, 64.

[2] Giumbelli, E. (2014) O campo religiosoemsuasconfigurações. In: Sena, E. and Sofiati, F., Eds., Novasleituras do campo religiosobrasileiro, Ideias \& Letras, São Paulo, 153-175.

[3] Hervieu-Léger, D. (1999) Le pèlerin et le converti. Flammarion, Paris.

[4] Paiva, J.G. (2004) Identidade e Pluralismo: Identidade Religiosa em Adeptos Brasileiros de Novas Religiões Japonesas. Psicologia: Teoria e Pesquisa, São Paulo, Vol. 20, 21-29.

[5] Truzzi, O.M.S. (1993) Patrícios-Sírios e Libaneses em São Paulo. Unesp, Campinas.

[6] Paiva (2004) Idem.

[7] (2010) Census 2010, IBGE, Data on Religion. http://censo2010.ibge.gov.br/noticias-censo?view=noticia\&id=3\&idnoticia=2170\&busca=1\&t=censo-2010-numero-cat olicos-cai-aumenta-evangelicos-espiritas-sem-religiao

[8] Mariano, R. (1999) Neopentecostais. Sociologia do novo pentecostalismo. Loyola, São Paulo.

[9] Souza, A.R. (2014) Um balanço do catolicismocarismático. In: Sena, E. and Sofiati, F., Eds., Novasleituras do campo religiosobrasileiro, Ideias \& Letras, São Paulo, 141-150. 
Scientific Research Publishing (SCIRP) is one of the largest Open Access journal publishers. It is currently publishing more than 200 open access, online, peer-reviewed journals covering a wide range of academic disciplines. SCIRP serves the worldwide academic communities and contributes to the progress and application of science with its publication.

Other selected journals from SCIRP are listed as below. Submit your manuscript to us via either submit@scirp.org or Online Submission Portal.
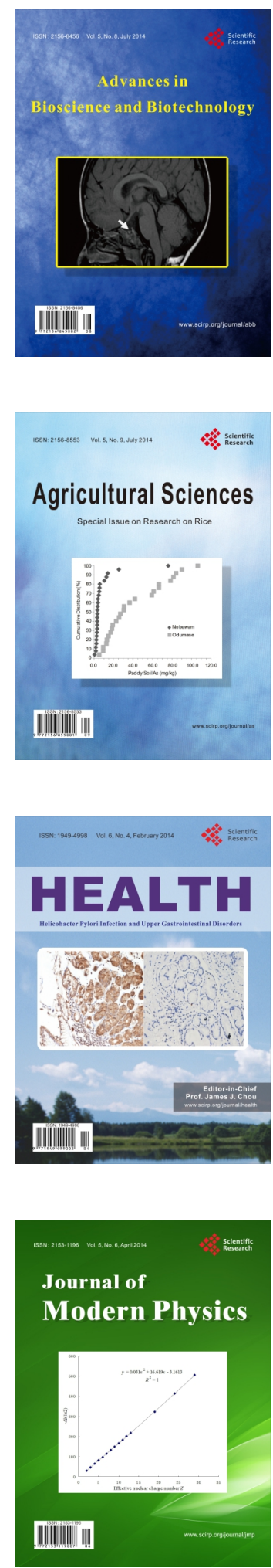
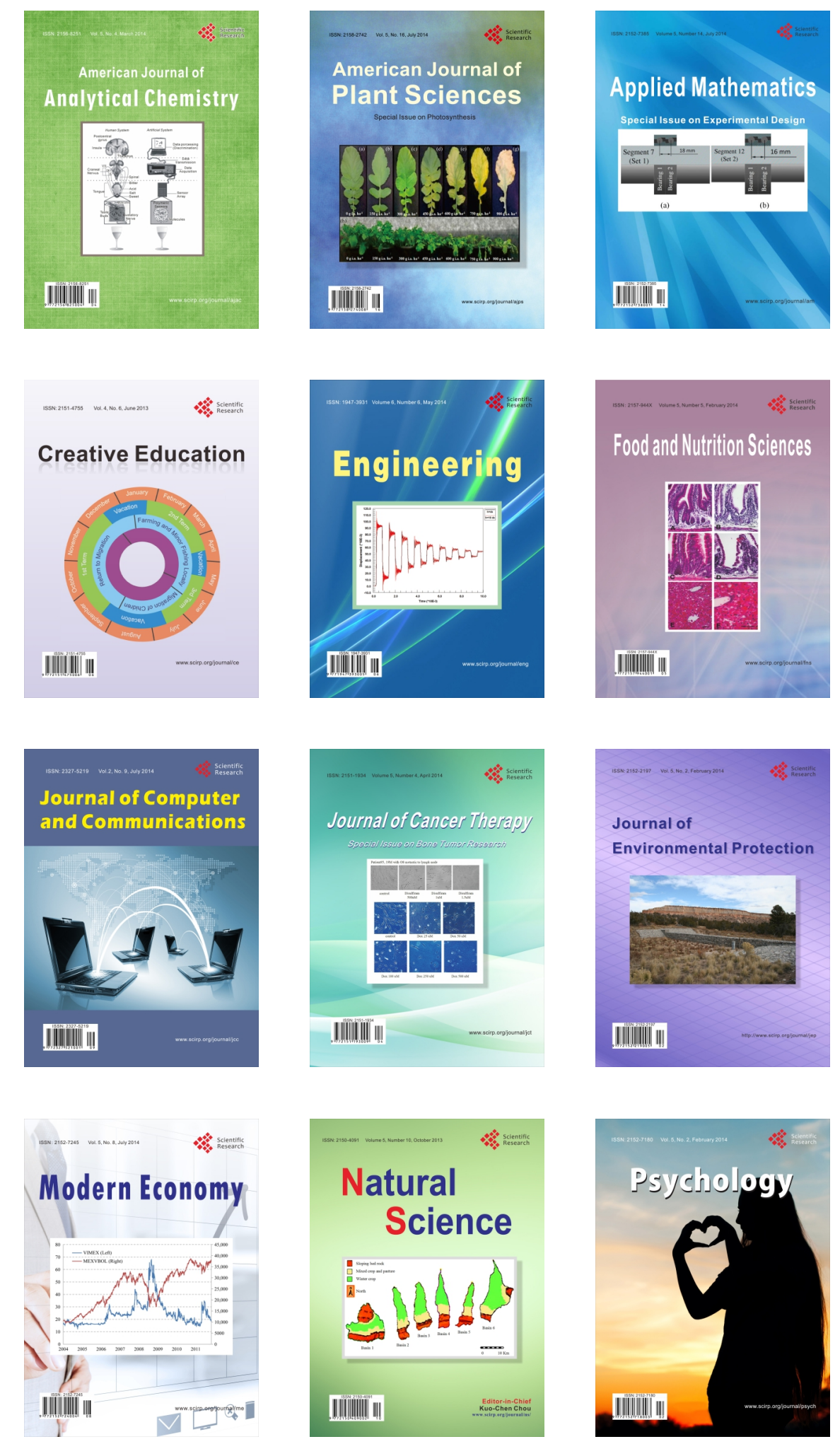